\title{
Estimation of Rate and Time Delay for underground Mumbai Metro Corridor by using Monte Carlo Simulation
}

\author{
Abhishek Lowe, Karthik Nagarajan, Raju Narwade
}

\begin{abstract}
Globally the utilization of metros is incredibly common for transportation for convey individuals at one place to a different for convey individuals at one place to a different with ease. Infrastructure os Asian nation project ill-framed for time delay and rate value flooded. Globally there many analysis for estimating cost and time delay with analytical, case study and downside that are the factors inflicting time delay and rate value flooded which are found by using Rankin's constant techniques, Risk performance technique, Time delay and cost overrun index, CPM \& PERTS, Monte's Carlo Simulation Techniques, Budget dominant and change and Milestone chart etc are such type of methodologies applies to seek out project's time delay and cost overrun in Infrastructure project. This paper the methodology accustomed ascertain expected time and cost in Mumbai underground metro rail passageway (MUMRP) by victimization application of Monte's Carlo Simulation Techniques (MCST), during this we have a tendency to use network flow chart for locating out trial and error based mostly to create activities as essential path technique (EPT) by given downside statement and also outcome in terms of results and conclusion.
\end{abstract}

Keywords: EPM, Metro Corridor, Monte's Carlo Simulation Techniques (MCST), PERT, Time Delay

\section{INTRODUCTION}

Risk Management is a vital and primary a component of project management in foremost manufacture comes. on behalf of associate communications task, risk management are often administrate effectively by work and distinctive the source of risks related to every action of the project. These risk are often assess or calculated within conditions of likelihood and collision for the reason that for delay and cost value overrun in comes.

Globally the metros is extremely common for transportation for convey individuals at one to a different with ease. In Asian nation the cities wherever population over 1-10 million and because of that the hold up the road accident is a lot of common in that cities the role of tube rail is extremely necessary to scale back such drawback incidence in future. Infrastructure of Asian nation project ill framed for time hindrance and rate value flooded. A construction project is often admitted as in once it complete on time with budget, according the specifications, and neutral satisfaction.

Revised Manuscript Received on June 13, 2020.

* Correspondence Author

Abhishek Lowe*, Department of Civil Engineering, Pillai HOC College of Engineering and Technology, Rasayani, Panvel, Maharashtra, India. E-mail: abhisheklowe14@gmail.com

Karthik Nagarajan, Department of Faculty of Civil Engineering, Pillai HOC College of Engineering and Technology, Rasayani, Panvel, Maharashtra, India. E-mail: knagarajan@mes.ac.in

Raju Narwade, Department of Faculty of Civil Engineering. Pillai HOC College of Engineering and Technology, Rasayani, Panvel, Maharashtra, India. E-mail: rnarwade@mes.ac.in

(C) The Authors. Published by Blue Eyes Intelligence Engineering and Sciences Publication (BEIESP). This is an open access article under the CC BY-NC-ND license (http://creativecommons.org/licenses/by-nc-nd/4.0/)

Several of them mentioned concerning time delay and asking price flooded and their factors meant for inflicting occasion delay and rate flooded in project.

The key actions in underground metro corridor structure consist of viability study, plan passage change ,review works ,bear strut and king post piling works ,lumber covering works ,top soil, rock and muck excavation ,structure decking ,toughen struts ,rocks anchor , slabs ,drainage , wet and spray waterproofing ,eternal structure works ,mechanical and electrical installations ,sand backfilling and reinstallation works.

The feasibility stage of the project is a supplementary five year.The resultant system diagram is given in Figure $1 \mathrm{a}$ few supplementary projects information be furnish in Appendix 1.

\section{LITERATURE REVIEW}

Arya Vijayan et al. (2019) used IoT based architecture for monitoring water leakage which can be referred for metro tunnel construction where roof leakage is an major issue, Biradar Shilpa et al. (2019) has found an alternative partial replacement for coarse aggregate by using $\mathrm{E}$ waste concrete by which time delay can be reduced in material management. Chowdary Mohanlal et al. (2019) has applied 4D GIS technique for labour management in Uran area in Maharashtra which time delay can be reduced in material management. Chowdary Mohanlal et al. (2019) has applied 4D GIS technique for labour management in Uran area in Maharashtr which can be implemented for major infrastructural construction industry. Chhaya Zende et al. (2019) has found a reusable formwork manufacturing technique which can be used for future cities metro line developments etc. Mahesh S. Singh et al. (2019) has research in labour productivity by using R II method whereas Sanika Kandalekar et al. (2019) has worked on feasibility of pervious concrete pavements. Pradnya Patil et al. (2019) has emphasised on how to apply PVA fibres using NDT test and Pallavi Patil et al. (2019) has developed a method termed as re modified minimum moment method for resource management for infrastructural projects. Shobhana Jadhav et al. (2019) has used GIS to find the shortest possible route for material transport management which is a major part for metro management across big cities. Pravin Shahi et al. (2018) revealed that the deployment of well skilled manpower at site can help to save significant amount of repairing and rehabilitation budget as well as reduction of project duration period without impeding any quality parameter.

Blue Eyes Intelligence Engineering \& Sciences Publication (C) Copyright: All rights reserved.

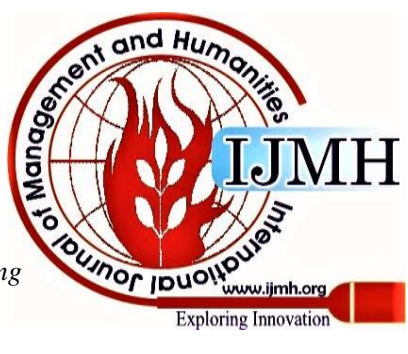




\section{Estimation of Rate and Time Delay for underground Mumbai Metro Corridor by using Monte Carlo}

Simulation

Prathamesh Brid et al. (2017) we used both fuzzy AHP and Vikor method for decision making where the results demonstrate the usefulness and effectiveness of the modified new method.

Sunil A. Kage et al. (2017) studied rate flooded be single in every of the essential issue within currently days thus needs a great deals of analysis and exploration to overcome or cut back the delay and fewer variation in take into account the longer term comes. A cost overrun is outlined as a cost rises or budget overrun, involves sudden cost incurred in far more than the budget amount of sarcasm of the particular cost budgeting of construction projects. Most construction projects in Asian nation are influenced through flooded in rate and delay in occasion. Rathi et al. (2013) deliberate completely diverse literatures associate with rate flooded and its cause originate that wrong estimate and style change lead project to detain and additionally have an effect on the cost at the time of construction. This may facilate the possessor or organization to require call related procurement of resources at correct time along with completes the project among lapsed time. Alhomidan et al. (2015) here their analysis on construction project illustrated with the purpose of once plan rates are expeditiously supervised whereas the opposite circumstances unbroken stable, as production task progresses, a balanced increment within their prices or else worth be recorded. Additionally, once construction project's predictable or deliberate cost is magnified, a co-occurring boost in their virtual actual rate should crop up.. However, though' observance will expeditiously cut back the project's rate flooded, the longer construction projects holdup develop into the superior rate overruns. Mr. Singh's (2017) analysis complete with the intention of the most important cause accountable used for delay of production project in Asian nation consist of: the implementation processes, inadequacy in project plans, contracts and procedures. Sadi A. Assaf, Sadiq Al-Hejji (2006) during this review on occasion presentation of various kinds of production project in Kingdom of Saudi Arabia was conduct to work out the cause of holdup and their significance consistent with every of the task participant, i.e., the possessor consultant and therefore the supplier The land study conduct integrated 23 contractor, 19 consultant, and owner. Seventy-three cause of stoppage were known throughout analysis. All 3 parties is "modify arrange". Survey complete that $70 \%$ of projects practiced occasion flooded and located that that 45 out of 76 projects measured were overdue. The foremost common reason behind delay known by $76 \%$ of the contractor and $56 \%$ of the consultant indicate to facilitate common of occasion flooded is between $10 \%$ and $30 \%$ of the primary interval.

\section{A. Gaps}

Project might arise as factors may affects time delay and cost overrun as are follows :

Poor site management and performance, Late release of fund, Irrelevant planning and scheduling, Man power shortage , Risk management in all activities, Delay in expected time duration of project and Cost overrun in project Improper accomplishment in execution of civil structure causes unhealthy quality and time overrun and further repair and different services charges causes for cost overrun on the project.

\section{B. Objective}

To seek out expected time and cost of the infrastructure project underground Metro rail corridor by using application of Monte Carlo simulation Method (MCSM). During this we have a tendency to use network flow diagram and activities bar graph with facilitate of Primavera P6 Planning coming up with software system for locating out trial and error based mostly to create activities as essential path method (EPM).

\section{Project Case Study}

The projects measured for study construction of Mumbai metro underground rail operation into primary metros of a promising financially viable state in India .Phase consist of the project plan of about $33.5 \mathrm{Km}$ stretch with 26 station and including 2 depot .An anticipated capital cost of phase is about INR 110 billion. The main contractor play role as a joint venture (JV) consisting of seven foreign contractors as partners and seven domestic contractors with four General Consultants and Client MMRCL. The category of agreement is based on a Design Build Turnkey (DBT) wherever primary contractor importantly to plan the underground metro and carry out the project. The project rate for an implementation of $6.6 \mathrm{kms}$ is concerning INR 28.3 Crores and in USD 453 million. The agreement phase is concerning five years (exclusively for execution).

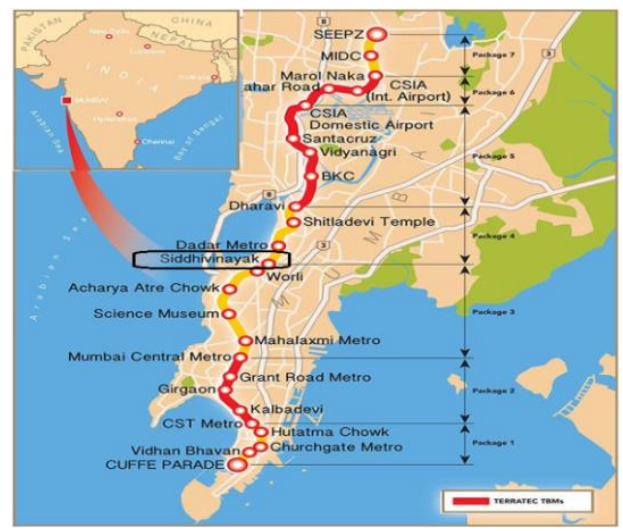

Figure 1. Siddivinayak Metro Station - Study area Source: http://news.railanalysis.com/terratec-tbm-completes-firsttunnel-for-mumbai-metro

\section{METHODOLOGY}

The planning scheduled activities developed with network flow diagram with application of CPM \& PERT and their price and time is formulated with the applying of Monte Carlo simulation method (MCSM). Methodology has been urbanized by making inter-relationship involving current infrastructure activities of creating metro construction schedule by exploitation Primavera project P6 for programming of activities that be being intended and programmed relying upon the WBS (work breakdown structure). The subsequent methodology encompasses management.

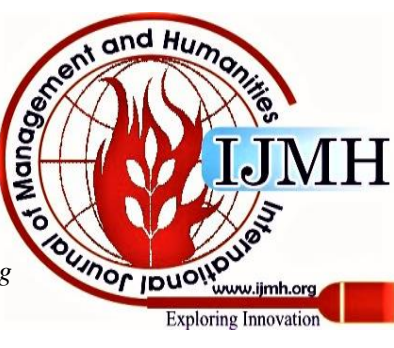




\section{Management Approach}

\section{A.1. Identifying Activities}

For any construction project, planning and scheduling with numbers of construction actions be essential to be accomplished for achievement of task. The actions and procedures are to be determined by achievement of series. A methodical work breakdown structure is being organized using top to underneath approach with depending upon the sequences of activities. To create the project series more well-organized and controllable. It's very essential to create work breakdown structure. Primavera Project adds completed structural components for scheduling of the construction such as follows Beams, Slabs, PCC, Plinth Beam, Piles, Base slab, overhead water tank, Permanent wall, elevation structure and underground structure

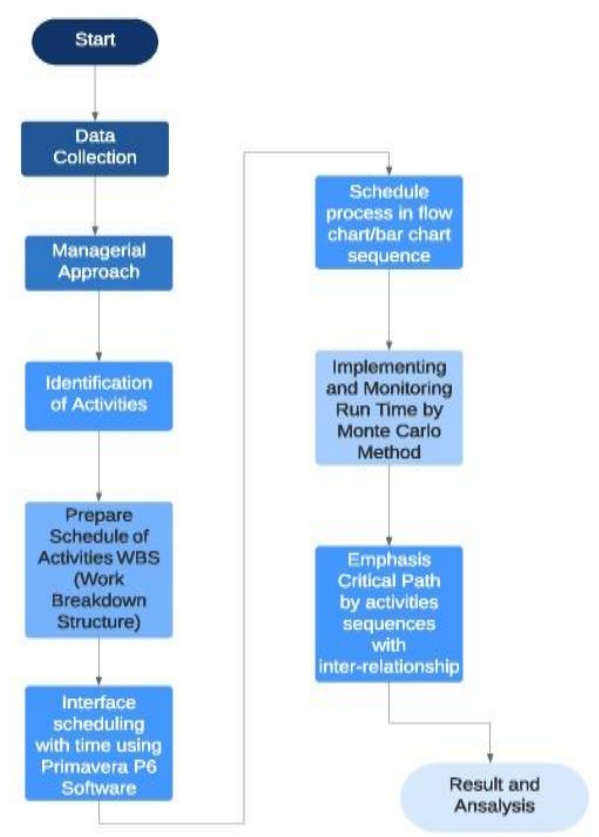
Fgure 2. Flowchart Sequence for scheduling of WBS and
development of Critical Path.

A.2. Prepare WBS and update schedule with time and emphasize Critical path

As in fig no-02 scheduling activities of structural activities key dates are showing all the planned and scheduling of activities are depends on the work break down structure. Microsoft project or Primavera project was used for scheduling activities. While planning the activities important to create WBS after that its interrelated to give name of activities and show when action opening and while its finish, its period, percentage completion consummate by vital path, its action series and their inter-relationship. The program should be restructured at any time is their change in achievement of task or holdup in task from time to time. Schedule must have made to be up to date for obtaining accuracy in actual performed task for getting desirable planned task.
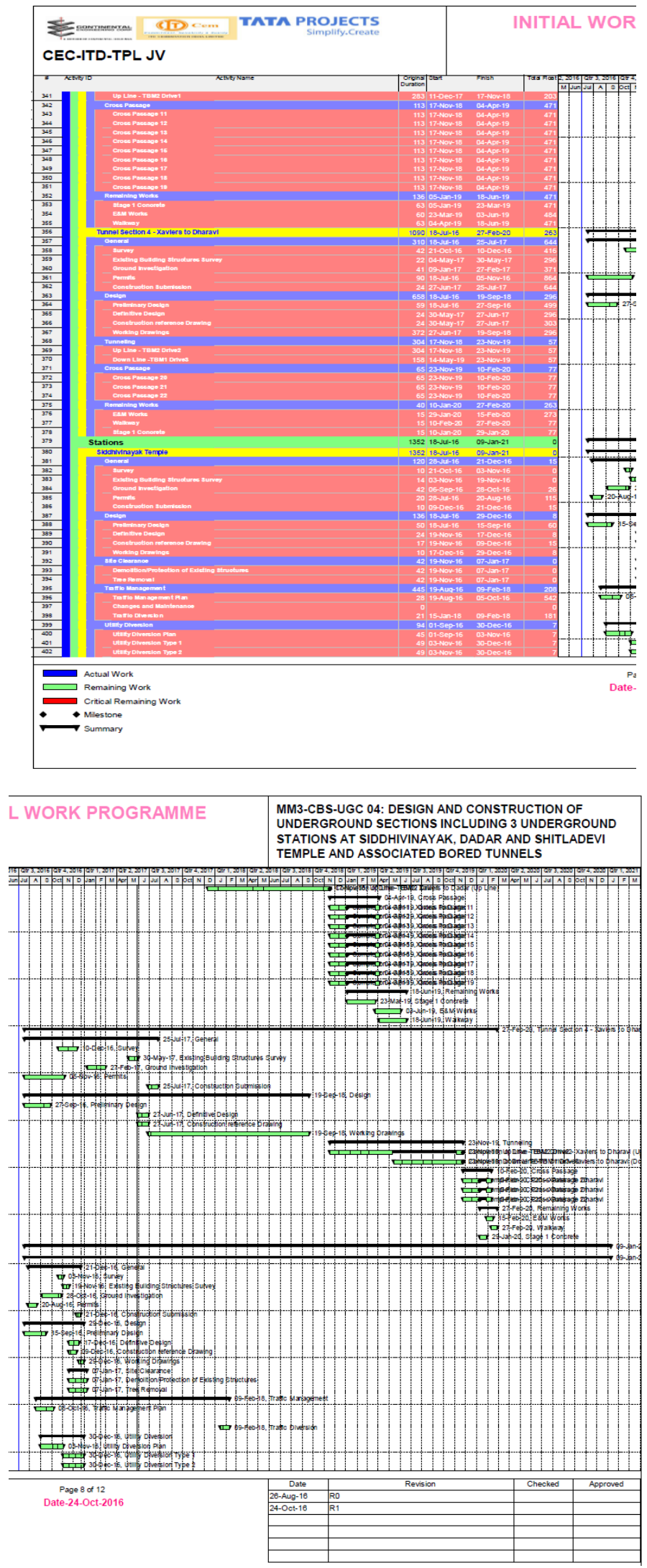

Figure 3. Scheduling activities of structural Activities Key Dates

KEY DATE FOR TUNNEL MACHINE

Published By:

Blue Eyes Intelligence Engineering

\& Sciences Publication

DOI:10.35940/ijmh.J0965.0641020

Journal Website: www.ijmh.org

(C) Copyright: All rights reserved.

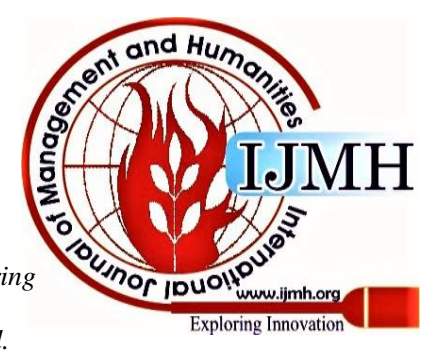




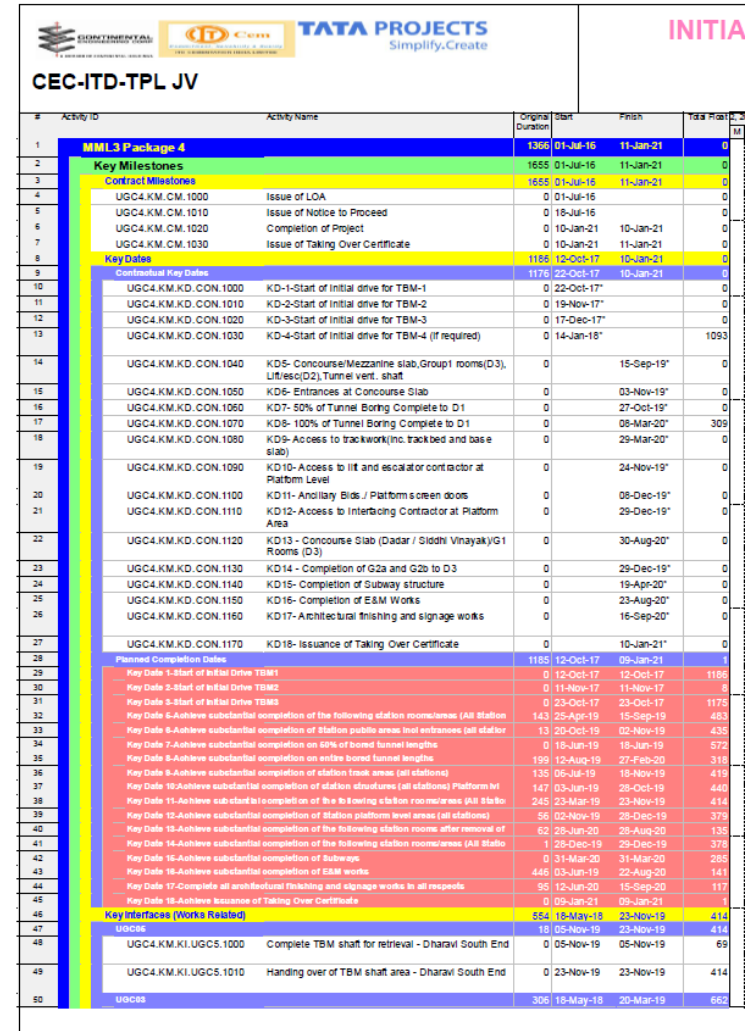

Key Date For Tbm Initial Drive and Final Drive TBM Breakthrough

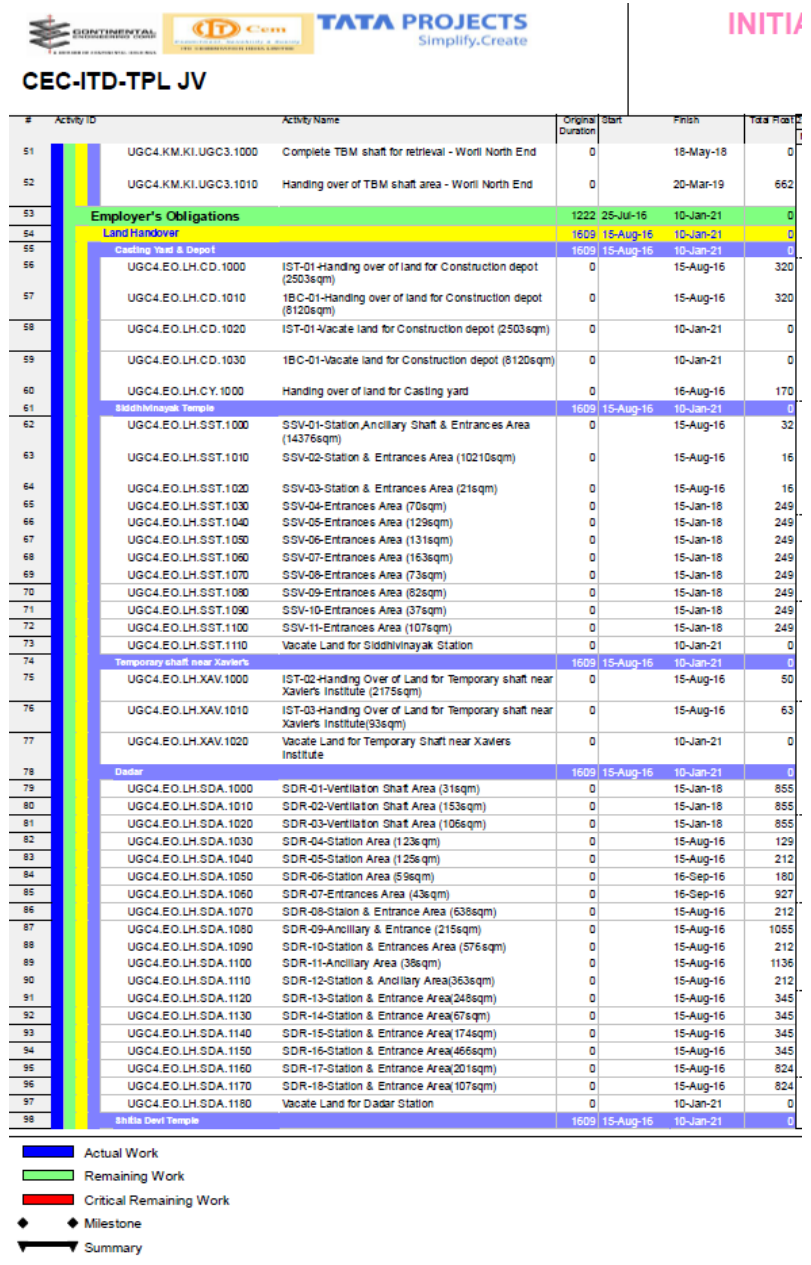

Figure 4. Ellaborated Activities list With Key Dates

\section{A.3. Schedule planning progress in flow charts/Bar charts sequence}

The Auto setting up program be conceive headed for assist the formation of planning into the outward appearance of the bar chart (Gantt chart) be used in favor of the symbol of a project within the activities are represented by parallel segments, of which the duration is relative to the time essential to finish the job in question. The bar chart is a successful tool used for the managing of job in a project. In this Auto Planning program, is complete up: A planning sheet or is introduced the variety of works by the initial and finish date of work. If essential, input the percentage of progress of the work.

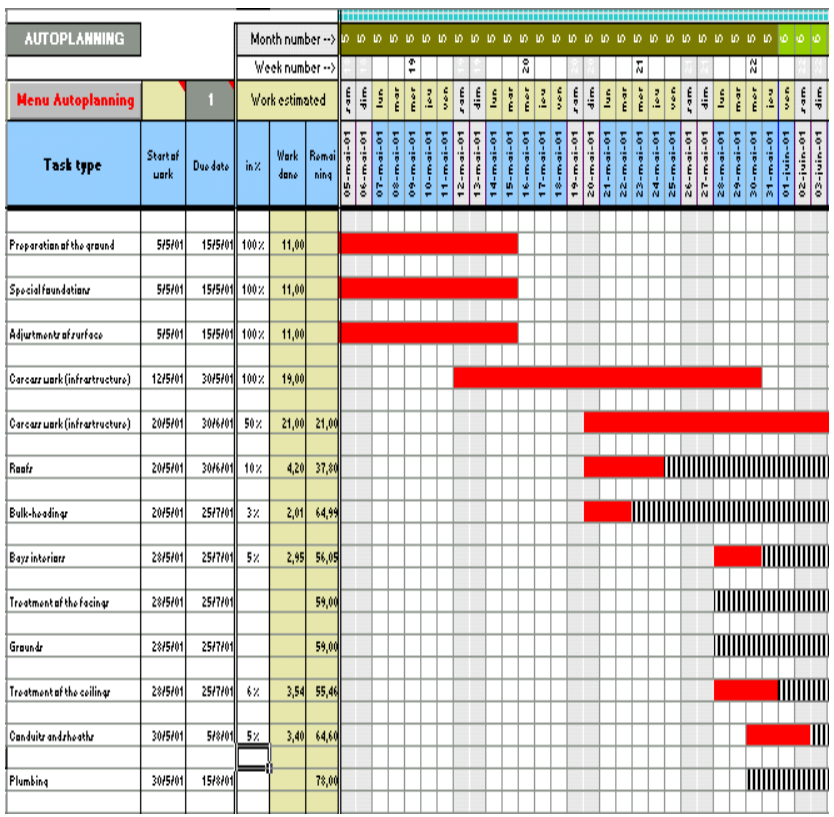

Figure 5. Planning schedule in bar chart

Within set off on this sheet:

- Control to replacement the planning sheet, condition essential.

- Control to generate a Gantt chart on a definite sheet.

- Control of placing of matching columns.

\section{ANALYSIS}

A. 1mplementing and Monitoring Run Time by Monte Carlo Method- appliance of Monte's Carlo Simulation

As concern that the Monte's Carlo simulation toward forecast the end result for anticipated time (AT) and anticipated cost (AC) of all the potential methods of performance shown in the complex diagram and design of the project (figure 6). The Monte Carlo simulation conjointly consideration the penalty of close to essential methods turning into critical. By concluding an in depth path investigation of the project network flow diagram, we tend to determined so as to an activity path sequence A-C-ED-G-I-P-T has the greatest interval of length 3700 days.

Published By:

Blue Eyes Intelligence Engineering

\& Sciences Publication

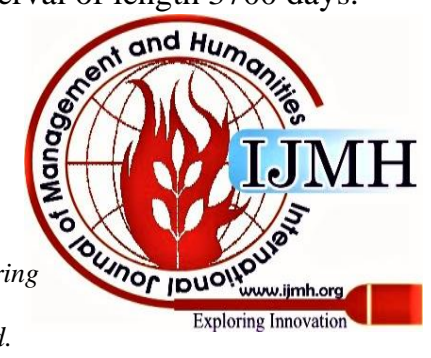


Thence is this path is taken into account because the essential path of the project system (refer figure 6). The equivalent rate for the end of activities on in this path is INR 1220 Million. It's conjointly determined that the chance of the flourishing conclusion of the project inside the set occasion and rate frame is only $5 \%(0.605 \times 0.700 \times 0.850 \times$ $0.631 \times 0.700 \times 0.623 \times 0.716 \times 0.702=0.050)$. Path A-BD-G-I-P-T could close to essential path with a chance of regarding $5 \%$ for successful achievement inside the set occasion and rate frame. There are possibilities for this path turning into essentials

Table 1. Key Activities and their occasion estimate for Underground Metro Line 3 Mumbai Project

\begin{tabular}{|c|c|c|c|}
\hline Activity & Description & IP & $\begin{array}{c}\text { Duration } \\
\text { (Days) }\end{array}$ \\
\hline A & $\begin{array}{c}\text { Achievability } \\
\text { Studies }\end{array}$ & - & 250 \\
\hline B & Plan & A & 100 \\
\hline C & $\begin{array}{l}\text { Technology } \\
\text { Selection }\end{array}$ & A & 90 \\
\hline D & $\begin{array}{c}\text { Traffic } \\
\text { diversion }\end{array}$ & $\mathrm{B}, \mathrm{E}$ & 120 \\
\hline $\mathbf{E}$ & $\begin{array}{l}\text { Utility } \\
\text { diversion }\end{array}$ & C & 120 \\
\hline $\mathbf{F}$ & Survey Works & B & 100 \\
\hline G & Piling works & $\mathrm{D}$ & 415 \\
\hline H & $\begin{array}{l}\text { Stagging } \\
\text { works }\end{array}$ & C & 340 \\
\hline $\mathbf{I}$ & $\begin{array}{c}\text { Soil } \\
\text { excavation }\end{array}$ & $\begin{array}{l}\text { G,F,H } \\
\text {,L }\end{array}$ & 400 \\
\hline $\mathbf{J}$ & $\begin{array}{c}\text { Rock } \\
\text { excavation, }\end{array}$ & $\mathrm{C}$ & 160 \\
\hline $\mathbf{K}$ & $\begin{array}{c}\text { Manufacture } \\
\text { and exaction } \\
\text { of production } \\
\text { decks }\end{array}$ & C & 160 \\
\hline $\mathbf{L}$ & $\begin{array}{l}\text { Rock anchor } \\
\text { installation }\end{array}$ & E,J & 437 \\
\hline $\mathbf{M}$ & $\begin{array}{l}\text { Rock anchor } \\
\text { stressing }\end{array}$ & $\mathrm{J}$ & 438 \\
\hline $\mathbf{N}$ & $\begin{array}{l}\text { Shotcreting } \\
\text { Rock bolting }\end{array}$ & $\mathrm{M}$ & 300 \\
\hline $\mathbf{0}$ & $\begin{array}{l}\text { Sub floor } \\
\text { drainage }\end{array}$ & $\mathrm{C}$ & 100 \\
\hline $\mathbf{P}$ & $\begin{array}{c}\text { Water } \\
\text { proofing base } \\
\text { slab }\end{array}$ & $\mathrm{Q}, \mathrm{K}$ & 220 \\
\hline $\mathbf{Q}$ & $\begin{array}{l}\text { Down to top } \\
\text { costruction }\end{array}$ & $\mathrm{O}$ & 300 \\
\hline $\mathbf{R}$ & $\begin{array}{l}\text { Permanent } \\
\text { Structure }\end{array}$ & $\mathrm{N}, \mathrm{P}, \mathrm{I}$ & 536 \\
\hline
\end{tabular}

Cont...

\begin{tabular}{|c|c|c|c|c|}
\hline Activity & ES & EF & LS & $\mathbf{L F}$ \\
\hline $\mathbf{A}$ & 0 & 250 & 0 & 250 \\
\hline B & 250 & 350 & 295 & 395 \\
\hline $\mathrm{C}$ & 250 & 340 & 250 & 340 \\
\hline D & 395 & 515 & 395 & 515 \\
\hline $\bar{E}$ & 340 & 420 & 380 & 460 \\
\hline $\mathbf{F}$ & 395 & 495 & 455 & 555 \\
\hline G & 515 & 880 & 515 & 880 \\
\hline $\mathbf{H}$ & 290 & 660 & 600 & 940 \\
\hline I & 880 & 1280 & 880 & 1280 \\
\hline $\mathbf{J}$ & 290 & 450 & 900 & 1060 \\
\hline $\mathbf{K}$ & 290 & 460 & 470 & 640 \\
\hline $\mathbf{L}$ & 370 & 807 & 370 & 807 \\
\hline $\mathbf{M}$ & 450 & 888 & 480 & 918 \\
\hline $\mathbf{N}$ & 460 & 760 & 625 & 925 \\
\hline $\mathbf{0}$ & 900 & 1000 & 920 & 1020 \\
\hline $\mathbf{P}$ & 1060 & 1280 & 1060 & 1280 \\
\hline $\mathbf{Q}$ & 900 & 1200 & 1000 & 1300 \\
\hline $\mathbf{R}$ & 964 & 1500 & 1024 & 1550 \\
\hline
\end{tabular}

\section{ES: Early Start; EF: Early Finish; LS: Late Start; LF; Late Finish ; IS: instantaneous predecessor}

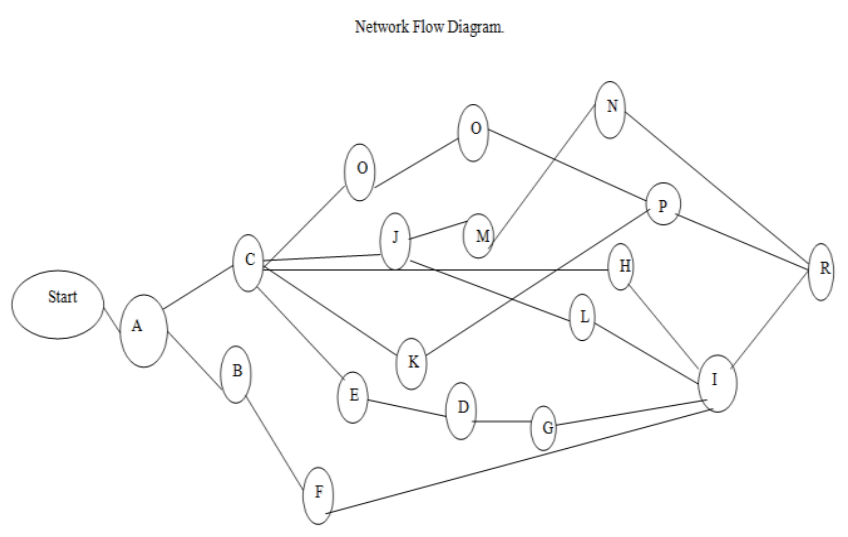

Figure 6. Network Flow Diagram

According to network flow diagram there are 7 path made out which most likely path is A-C-H-I-R and Essential path has found as path of A-C-E-D-G-I-R .So from when analysis results involves resolve presumably time shows path A-C-H-I-R and and base time period path of A-C-E-DG-I-R and there after analyzing of slack duration (SD) in task performance activities indicates the Time Delay Duration (TDD).

The function of the Monte Carlo simulation to the higher than path study resulted within the follow outcome:

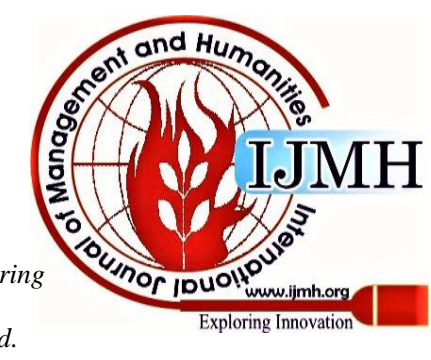


Estimation of Rate and Time Delay for underground Mumbai Metro Corridor by using Monte Carlo Simulation

Table II. Result of Path Analysis of the Project Network Diagram apply Monte Carlo Simulation

\begin{tabular}{|c|c|c|c|}
\hline Path & Action & $\begin{array}{c}\text { Path duration } \\
\text { ( days ) }\end{array}$ & $\begin{array}{c}\text { Cost (Rs. } \\
\text { Cr) }\end{array}$ \\
\hline 1 & A-B-F-I-R & 1775.77 & 119.28 \\
\hline 2 & A-C-E-D-G-I-R & 1875 & 122.28 \\
\hline 3 & A-C-O-Q-P-R & 1560.12 & 96.17 \\
\hline 4 & A-C-H-I-R & 1377.62 & 87.11 \\
\hline 5 & A-C-K-P-R & 1177.52 & 82.09 \\
\hline 6 & A-C-J-L-I-R & 1520.08 & 108.19 \\
\hline 7 & A-C-J-M-N-R & 1308.48 & 92.2 \\
\hline
\end{tabular}

\begin{tabular}{|l|l|l|l|l|l|}
\hline $\mathbf{B}$ & 90.280 & 113.320 & 384.280 & 13.320 & 30.707 \\
\hline $\mathbf{C}$ & 23.490 & 42.700 & 120.490 & 6.750 & 24.216 \\
\hline $\mathbf{D}$ & 113.600 & 54.000 & 588.600 & 8.000 & 23.915 \\
\hline $\mathbf{E}$ & 68.900 & 121.528 & 381.900 & 21.528 & 22.012 \\
\hline $\mathbf{F}$ & 44.100 & 11.557 & 332.100 & 15.570 & 15.313 \\
\hline $\mathbf{G}$ & 99.680 & 269.409 & 455.680 & 22.459 & 28.000 \\
\hline $\mathbf{H}$ & 43.750 & 23.992 & 281.750 & 19.960 & 18.382 \\
\hline $\mathbf{I}$ & 76.875 & 196.875 & 406.875 & 31.250 & 23.295 \\
\hline $\mathbf{J}$ & 58.800 & 103.520 & 223.800 & 29.400 & 35.636 \\
\hline $\mathbf{K}$ & 45.200 & 163.200 & 215.200 & 36.000 & 26.588 \\
\hline $\mathbf{L}$ & 177.025 & 389.425 & 867.025 & 29.808 & 25.655 \\
\hline $\mathbf{M}$ & 86.250 & 66.974 & 371.250 & 33.948 & 30.263 \\
\hline $\mathbf{N}$ & 63.455 & 104.113 & 323.455 & 30.141 & 24.405 \\
\hline $\mathbf{O}$ & 39.780 & 77.748 & 209.780 & 29.580 & 23.400 \\
\hline $\mathbf{P}$ & 36.480 & 151.949 & 156.480 & 26.624 & 30.400 \\
\hline $\mathbf{Q}$ & 31.970 & 76.458 & 176.970 & 27.429 & 22.048 \\
\hline $\mathbf{R}$ & 19.976 & 97.524 & 141.976 & 21.906 & 16.374 \\
\hline & & & & & \\
\hline
\end{tabular}

Table III. Anticipated Cost and Time Analysis for the Project

\begin{tabular}{|l|l|l|l|l|l|l|}
\hline Actiiy & $\begin{array}{l}(\mathrm{CL} \\
\mathrm{F}) \mathrm{j}\end{array}$ & $\begin{array}{l}\text { (BCA } \\
\text { ( }\end{array}$ & $\begin{array}{l}\mathrm{t} \\
(\mathrm{CC}) \mathrm{j}\end{array}$ & $(\mathrm{RR}) \mathrm{j}$ & $\begin{array}{l}(\mathrm{BTA} \\
) \mathrm{j}\end{array}$ & $(\mathrm{CT}) \mathrm{j}$ \\
\hline A & 0.35 & 238 & 60 & 21 & 1875 & 1130 \\
\hline B & 0.37 & 100 & 36 & 13.32 & 294 & 244 \\
\hline C & 0.27 & 40 & 10 & 2.7 & 97 & 87 \\
\hline D & 0.32 & 50 & 12.5 & 4 & 475 & 355 \\
\hline E & 0.26 & 100 & 82.8 & 21.52 & 313 & 265 \\
\hline F & 0.18 & 10 & 8.65 & 1.557 & 288 & 245 \\
\hline G & 0.28 & 220 & 176.4 & 49.41 & 356 & 356 \\
\hline H & 0.25 & 20 & 15.97 & 3.99 & 238 & 175 \\
\hline I & 0.38 & 150 & 125 & 46.88 & 330 & 205 \\
\hline J & 0.42 & 80 & 56 & 23.52 & 165 & 140 \\
\hline K & 0.40 & 120 & 108 & 43.2 & 170 & 113 \\
\hline L & 0.37 & 300 & 245 & 89.43 & 690 & 485 \\
\hline M & 0.35 & 50 & 49.2 & 16.97 & 285 & 250 \\
\hline N & 0.34 & 80 & 70.3 & 24.11 & 260 & 185 \\
\hline O & 0.31 & 60 & 58 & 17.75 & 170 & 130 \\
\hline P & 0.38 & 120 & 83.2 & 31.95 & 120 & 95 \\
\hline Q & 0.28 & 60 & 59.2 & 16.46 & 145 & 115 \\
\hline R & 0.23 & 80 & 77.2 & 17.52 & 122 & 88 \\
\hline
\end{tabular}

Cont...

\begin{tabular}{|c|l|l|l|l|l|}
\hline Activity & (RT)j & (AC)j & (AT)j & $\begin{array}{l}\text { AC\% } \\
> \\
\text { BCA }\end{array}$ & $\begin{array}{l}\text { AT\% } \\
\text { BTA }\end{array}$ \\
\hline A & 395.500 & 259.000 & 2270.500 & 8.824 & 21.093 \\
\hline
\end{tabular}

Tabular form of Base Cost anticipate and Anticipated Cost

\begin{tabular}{|c|c|c|}
\hline Activity & $\begin{array}{l}\text { Base cost } \\
\text { anticipate (BCA)j }\end{array}$ & $\begin{array}{l}\text { Anticipated Cost } \\
\text { (AC)j INR } \\
\text { Billion }\end{array}$ \\
\hline A & 238 & 259 \\
\hline B & 100 & 113.32 \\
\hline $\mathrm{C}$ & 40 & 42.7 \\
\hline $\mathrm{D}$ & 50 & 54 \\
\hline $\mathrm{E}$ & 100 & 121.528 \\
\hline $\mathrm{F}$ & 10 & 11.557 \\
\hline$G$ & 220 & 269.4088 \\
\hline $\mathrm{H}$ & 20 & 23.99 \\
\hline I & 150 & 196.875 \\
\hline $\mathrm{J}$ & 80 & 103.52 \\
\hline $\mathrm{K}$ & 120 & 163.2 \\
\hline $\mathrm{L}$ & 300 & 389.425 \\
\hline $\mathrm{M}$ & 50 & 66.974 \\
\hline $\mathrm{N}$ & 80 & 104.1129 \\
\hline $\mathrm{O}$ & 60 & 77.748 \\
\hline $\mathrm{P}$ & 120 & 151.9488 \\
\hline $\mathrm{Q}$ & 60 & 76.4576 \\
\hline $\mathrm{R}$ & 80 & 97.5244 \\
\hline
\end{tabular}

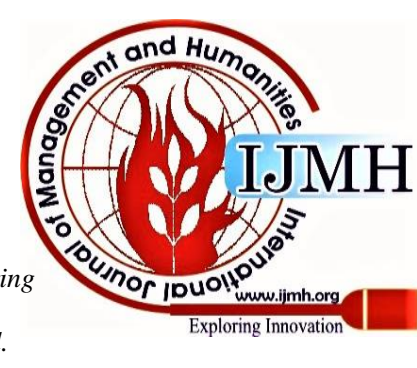


Table V. Tabular form of Base Time anticipate and Anticipated Time

\begin{tabular}{|l|l|r|r|r|r|r|r|r|r|r|r|r|r|r|r|r|r|r|}
\hline Activity & A & B & C & D & E & F & G & H & I & J & K & L & M & N & O & P & Q & R \\
\hline $\begin{array}{l}\text { Base } \\
\text { Time }\end{array}$ & $\begin{array}{l}187 \\
5\end{array}$ & 294 & 97 & 475 & 313 & 288 & 356 & 240 & 330 & 165 & 170 & 690 & 285 & 260 & 170 & 120 & 145 & 122 \\
\hline $\begin{array}{l}\text { Anticip } \\
\text { ated } \\
\text { Time }\end{array}$ & $\begin{array}{l}227 \\
0\end{array}$ & $\begin{array}{l}384 \\
2\end{array}$ & $\begin{array}{l}120 \\
9\end{array}$ & $\begin{array}{l}588 \\
6\end{array}$ & $\begin{array}{l}381 \\
9\end{array}$ & 332 & 456 & 282 & 407 & 224 & 215 & 868 & 371 & 323 & 210 & 156 & 177 & 142 \\
\hline
\end{tabular}

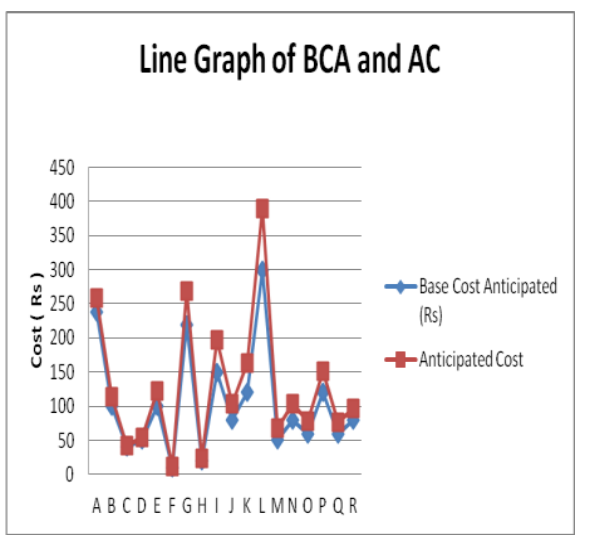

Fig 7.Cost Chart shows between Base Cost Anticipated and Anticipated Cost

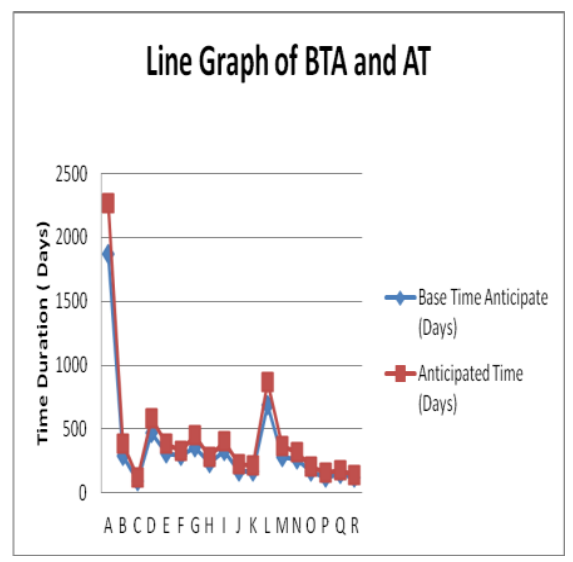

Fig 8.Chart difference between Base time anticipated and anticipted time

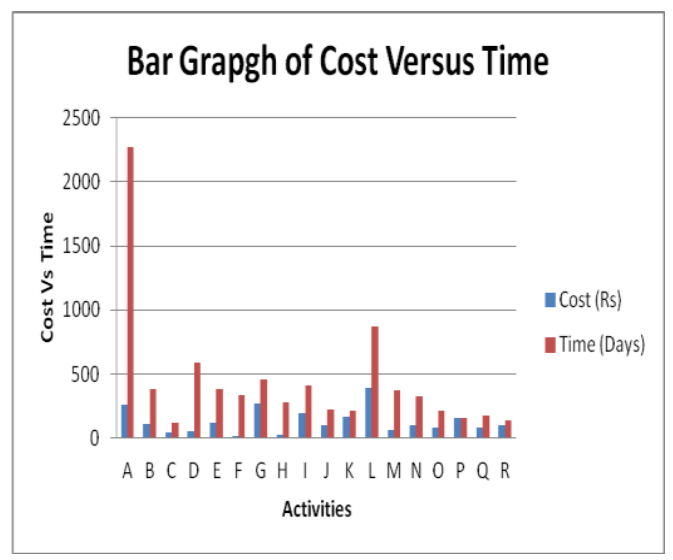

Fig 9. Chart Shows Cost Vs Time
Table 6. Project Anticpated Cost and Time Analysi

\begin{tabular}{|c|c|c|c|c|c|}
\hline $\begin{array}{c}\text { BRA } \\
\text { (INR } \\
\text { Bilion) }\end{array}$ & $\begin{array}{c}\text { RR } \\
\text { (INR } \\
\text { Billion) }\end{array}$ & $\begin{array}{c}\text { BTA } \\
\text { (Days) }\end{array}$ & $\begin{array}{c}\text { RT } \\
\text { (Days) }\end{array}$ & $\begin{array}{c}\text { AR(INR } \\
\text { Billion) }\end{array}$ & $\begin{array}{c}\text { AT } \\
\text { (Days) }\end{array}$ \\
\hline 28.3 & 4.9 & 1538.75 & 336.25 & 33.2 & 1875 \\
\hline
\end{tabular}

At the same time as per Figure 6. which represent the critical path diagram of the whole project of the underground corridor construction, and Table 4, As activity A (Achievability studies) the CLF is 0.348 as comes from the reaction of the feedback. The base rate anticipate (BRA)j for the activity achievability studies (A) is INR 240 Million, the corrective rate (CR)j is INR 60 Million (assumed in consultation with experts); the base time estimate (BTA)j is 1538.75 days; the corrective time (CT)j is 1130 days (assumed in conference with expert).

So as equation Risk rate $(\mathrm{RR}) \mathrm{j}=0.348 \times 60 \times 106=\mathrm{INR}$ 20.88 x 106; Risk time $(\mathrm{RT}) \mathrm{j}=0.348 \times 1130$ days $=336.25$ days.

So equations an anticipated rate

$(\mathrm{AR}) \mathrm{j}=\mathrm{BRAj}+\mathrm{RRj}=\mathrm{INR} 33.20$ Billion, anticipated time $(A T) j=B T A j+R T j=1875$ days.

A same to same calculation to be taken out for activities B, C, D.... and R (refer Table 4).

Now an anticipated rate (AR) project of the entire project of underground corridor construction has been calculated as follows:

Base Rate Anticipated (BRA)Project = INR 28.3 Million.

Risk Rate (RR)Project=INR 4.9 Billion

Anticipated Rate $(\mathrm{AR})$ Project $=($ BRA $)$ Project $+(\mathrm{RR})$ Project =INR 33.20 Billion

Anticipated Time $(\mathrm{AT})$ Project $=(\mathrm{BTA})$ Project $+(\mathrm{RT})$ Project $=1538.75+336.25$ duration in days

$=1875$ duration in days

So as per the study the AC of the project is $22.51 \%$ more preponderant than the BCA of the project. The AT of the project is $23.36 \%$ more preponderant than the BTA. Thus essential prognostication cerebrated about in favor of jeopardy management study the rate flooded shouldn't exceed $25 \%$ of the calculable base rate and ergo the time flooded should not be more preponderant than $30 \%$ of the calculable base time. Olympian these restrictions would increment the probabilities of the project turning into not as much of viable. The peril management study presages that the anticipated cost of the project is $22.51 \%$ more preponderant than the calculable base cost. This circumstance is prodigiously perturbing as it is the upper Published By: Blue Eyes Intelligence Engineering \& Sciences Publication

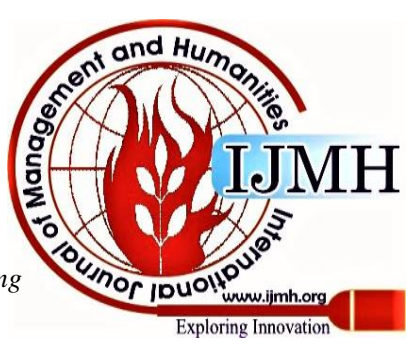


limit of the acceptable rate overrun. This example is profoundly meticulous designing and redress risk mitigation dealings to boost the possibility of achievement of the project.

An anticipated time presaged as of the analysis is $23.36 \%$ above than the calculable base time that is about to the higher limit of the acceptable time overrun. Consequently it's vital to sensibly go after the peril mitigation measures to corroborate that the project is accomplished closed to the orchestrated time frame.

\section{SEVERITY STUDIES of CLF and CIF}

Risk astringency may be compute from equation (6). The product of the likelihood and collision of a peril can be quantified as the astringency of that risk. This conception may be extensive for multiple risk source in an exceeding work parcel, the probability and collision of which may be articulated in terms of CLFj and CIFj severally. Consequently designed for the underground corridor construction project, the jeopardy rigor of every main activity of the project is calculated as conferred in Table 7.

The scale for the categorization of the risk astringency is articulated as:

\section{Table 7. Risk Astringency/Critical Categorization}

\begin{tabular}{|c|c|}
\hline $\begin{array}{c}\text { Astringency } \\
\text { /Critical }\end{array}$ & Categorization \\
\hline $0.000-0.030$ & Very Low/mild \\
\hline $0.030-0.050$ & Low/mild \\
\hline $0.050-0.150$ & Medium/Moderate \\
\hline $0.150-0.200$ & High \\
\hline $0.200-1.000$ & $\begin{array}{c}\text { Very } \\
\text { High/Severe }\end{array}$ \\
\hline
\end{tabular}

\section{CONCLUSION}

If most likely time is come in estimated time of project duration, then the project completion time is sufficient. In future scope there is vast in infrastructural time based project like bridges, Highways, airport ,Railways \& Metros etc . If most likelihood cost (MLC) come under the range (0.1 to 1 ) then project cost is in limit, but MLC greater than 1 than project will cause of cost overrun. So we find that the project has ran behind of almost two third year ( 256 days) and with cost overrun of 20-25\% approximately.

\section{ACKNOWLEDGMENT}

I would like to acknowledge MMRCL ( Mumbai Metro Rail Cooperation) for taking part in association and getting helps in making reports..

\section{REFERENCES}

1. Aditi Dinakar, (May 2014) "Delay Analysis in Construction Project" International Journal of Emerging Technology and Advanced Engineering ISSN 2250-2459, ISO 9001:2008 Certified Journal, Volume 4, Issue 5, May 2014

2. Arya Vijayan, Raju Narwade and Karthik Nagarjan (2019) : "Real Time Water Leakage Monitoring System Using IoT Based Architecture " International Journal for Research in Engineering Application \& Management (IJREAM), (Nov-2019), ISSN : 24549150, ,Vol-05, Issue-08, pp.24-30 , DOI : 10.35291/24549150.2019.0480

3. Biradar Shilpa, Karthik Nagarajan , Raju Narwade, Prof. Gayatri Deshpande ,(2019) : "E-Waste :An Alternative to Partial Replacement of Coarse Aggregate in Concrete “ , International Journal Of Engineering Research \& Technology (IJERT), (July-2019) ISSN: 2278-0181, Volume 08, Issue 07 (July 2019), pp.993-999

4. Chowdary Mohanlal, Karthik Nagarajan and Raju Narwade (2019) : "Applications of 4D GIS Model in Construction Management " International Journal of Innovative Technology and Exploring Engineering (IJITEE), (July-2019) ISSN: 2278-3075, Volume-8 Issue9, July 2019 , pp.2597-2608

5. Chhaya Zende, Karthik Nagarajan, RajuNarwade (2019) "Manufacturing Techniques of Sustainable Recyclable Formwork By A Smart Material Waste Composite Material (WCM) for Infrastructural Projects of Future Cities - A Swachh Bharat Abhiyan Initiative " , International Journal of Management, Technology And Engineering (IJMTE), (June-2019), ISSN NO : 2249-7455 ,Vol:9, Issue:6, pp.666-671

6. Debasis Sarkar \& Goutam Dutta “A Framework of Project Risk Management for the underground corridor construction of metro corridor" W.P. No. 2011-02-05 February 2011

7. Mahesh S.Singh, Raju Narwade, Karthik Nagarajan, Tejaswini D. N. (2019) : "Factors affecting the labour productivity of brickwork and analyzing them using RII method " International Journal of Advanced Technology and Engineering Exploration, (IJATEE), (May-2019), ISSN (Print): 2394-5443 ISSN (Online): 2394-7454, ,Vol-06,Issue-54, pp.143-151, DOI : 10.19101/IJATEE.2019.650043.

8. Nuhu Braimah, (2013) "Construction Delay Analysis TechniquesA Review of Application Issues and Improvement Needs" Buildings ISSN 2075-5309, pp. 506-531, 2013

9. Sanika Kandalekar, RajuNarwade and Karthik Nagarajan (2019) : "Feasibility of Pervious Concrete Pavement: A Case Study of Karanjade Node, Panvel " SSRG International Journal of Civil Engineering ( SSRG-IJCE )" ,(March-2019) , ISSN: 2348-8352 , Volume 6,Issue 3 - March 2019 , pp.35-40.

10. Pradhnya Patil, RajuNarwade and Karthik (2019) : "Effect of Marble Powder and PVA Fibres on the Strength and Microstructure of Engineered Cementitious Composite by using Non Destructive Test " SSRG International Journal of Civil Engineering ( SSRG-IJCE )" ISSN: 2348 - 8352, (March-2019) ,Volume 6,Issue 3 -, pp.51-57.

11. Pallavi Patil, Karthik Nagarajan and Raju Narwade (2019) : "Resource Management of Infrastructural Project for Future Cities: A Re Modified Minimum Moment method “ International Journal of Management, Technology And Engineering (IJMTE) , (Feb-2019), ISSN NO : 2249-7455, Vol:9, Issue:2, pp.1094-1099

12. Pravin Shahi and Raju Narwade (2018) "Optimization Measures and Techniques of Structural Assessment- A Non-Destructive Test Approach' International Journal of Civil Engineering and Technology (IJCIET) Volume 9, Issue 3, March 2018, pp. 906-913

13. Prathamesh Brid and Raju Narwade (2017) "Fuzzy AHP-Vikor Method for Decision Making for Residential Project" International Journal of Innovative Research in Science, Engineering and Technology, Vol. 6, Issue 8, August 2017, pp17136-17140

14. Rahman, M.M. and Kumaraswamy, M.M. (2002) "Risk Management Trends in the Construction Industry: Moving towards Joint Risk Management" Engineering Construction \& Architectural Management, Vol. 9(2), pp.131-151.

15. Sadi A. Assaf, Sadiq Al-Hejji, (2006) "Causes of delay in large construction projects" International Journal of Project Management 24, pp. 349-357, 2006

16. Shobana Jadhav, Karthik Nagarajan and Raju Narwade (2019) : "Best Feasible Transportation Route Analysis for Delivering Ready Mixed Concrete (RMC) - A Geographic Information System (GIS) Approach “ International Research Journal Engineering and Technology (IRJET)" , (Feb-2019) Vol:6, Issue:2, e-ISSN: 2395-0056, pPublished By: Blue Eyes Intelligence Engineering \& Sciences Publication

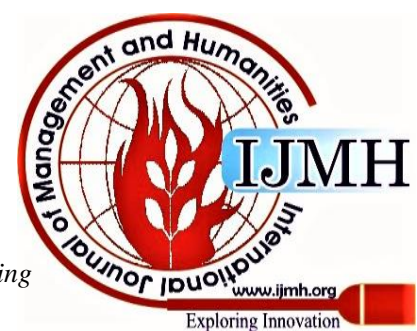


- Contributing towards promoting Geospatial Technology and its applications in Year 2018

- Certificate of appreciation as Network Institute Coordinator Award ( IIRS ISRO Outreach Program )

- First prize ( $14^{\text {th }}$ Maharashtra State Inter University ) Avishkar Research Convention 2019-20 organised by University of Mumbai on January 2020

- Silver Medal $\left(14^{\text {th }}\right.$ Maharashtra State Inter-Collegiate/Institue/Department ) Avishkar Research Convention 2019-20 organised by University of Mumbai on January 2020

- Life member of various international and national professional bodies like ISTE, ISH, ISRS, IAHS, IWWA, IAHR, ISPRS

\section{AUTHORS PROFILE}

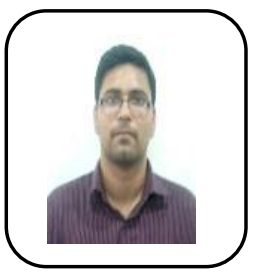

Name: Abhishek Lowe

Department: Civil Engineering

Email: abhisheklowe14@gmail.com

College Name: Pillai HOC College of Engineering and Technology, Rasayani, Panvel, Maharashtra.

Mobile No. 7506646048

\section{Education}

- Btech in Civil Engineering From Lovely Professional University

\section{Experience}

- Have four year experience as Civil Engineer in Mumbai Metro Underground Project

- Have 3 years experience as a Lecturer in Pillai's College of engineering and Technology and G.V. Acharaya Polytecnic and Enginerring Institute

\section{Workshop and Seminar Attended}

- Attended one day National workshop on "Advances in Construction Engineering" Dated:11/04/2014.

- Attended two day workshop on "Workshop on ETABS" Dated: 29/03/2015.

- Attended one week short term training program on "Application of Remote Sensing and GIS in Disaster Management: Response, Recovery and Reconstruction" Dated:11/01/2018.

\section{Area of Interest}

- Construction Planner / Planning Engineer, Assistant Project Manager, Site Engineer, Billing Engineer, QC, BBS.

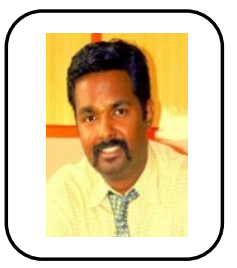

\section{Name: Karthik Nagarajan.}

Department: Faculty of Civil Engineering.

Email: knagarajan@mes.ac.in

College Name: Pillai HOC College of Engineering and Technology, Rasayani, Panvel, Maharashtra. Mobile No. 9819420975

\section{Education}

- Ph.D. (Pursuing): Mumbai University in Civil Engineering

- M.E. 2009: Mumbai University in Civil Engineering

- B.E. 2002: Mumbai University in Civil Engineering

\section{Research and Consultancy}

- Application of Remote Sensing and GIS in Water Resources

- Civil Engineering Department, Pillai HOC College of Engineering \& Technology, Rasayani

- Pursing Ph.D. in Water Resources with application of Remote sensing and GIS.

- Network Coordinator of IIRS, ISRO Outreach Centre, PHCET

- Areas of Interest

- Remote Sensing, GIS (Geographical information system), Water resources, Structural Engineering etc

\section{Awards and Recognitions}

- Received BEST NetworkInstitute Coordination Award (IIRS ISRO Outreach Program )

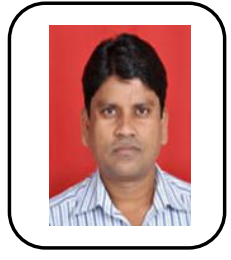

Name: Raju Narwade

Department: Faculty of Civil Engineering.

Email: rnarwade@mes.ac.in

College Name: Pillai HOC College of Engineering and Technology, Rasayani, Panvel, Maharashtra. Mobile No. 8108202122

\section{Education}

- Ph.D. (Pursuing): Mumbai University

- M.E. 2011: Mumbai University in Structural Engineering

- B.E. 1999: Shri Guru Gobind Singhaji College of Engineering and Technology, Nanded (MS)

Research and Consultancy

- Minor research Project Grant from University of Mumbai (2014)

- Minor research Project Grant from University of Mumbai (2017)

- ISRO Sponsored Research Work at Indian Institute of Remote Sensing, Deharadun (2018)

- Research work at Central Building Research Institute, Rorkee (Uttarakhand) (1996)

Courses

- UG Level: 1. Engineering Mechanics 2. Strength of Materials 3. Structural Analysis-I 4. Structural Analysis-II 5. Limit State Method Reinforced Concrete Structure 6. Reinforced Concrete Repair and Maintenance

- PG Level: 1.Repairs, Rehabilitation and Retrofitting of Structure 2. Advanced Construction Technology 3.Energy Conservation Techniques in Building Construction 4.Disaster Management and Mitigation Measures 5. Total Quality Management in Construction 5.Remote Sensing and Geographical Information System

\section{Important Publications}

1. Pravin Shahi and Raju Narwade (2018)" Optimization Measures and Techniques of Structural Assessment- A Non Destructive Test Approach" International Journal of Civil Engineering and Technology, Volume 9, Issue 3, March 2018, pp. 906-913, http://www.iaeme.com/MasterAdmin/Journal_uploads/IJCIET/VOLUME_ 9_ISSUE_3/IJCIET_09_03_090.pdf

2. Prathamesh Brid and Raju Narwade (2017) "Fuzzy AHP-Vikor Method for Decision Making for Residential Project" International Journal of Innovative Research in Science, Engineering and Technology, Vol. 6, Issue 8, August 2017. (https://www.ijirset.com/upload/2017/august/208_\%20prathamesh_paar pdf)

3. Prathamesh A. Brid and Raju Narwade (2017), "Fuzzy logic use for Decision-making in Construction Industry" published in International Journal on Recent and InnovationTrends in Computing and Communication (IJRITCC) Vol. 5 Issue $5, \quad$ May 2017.(www.ijritcc.org/download/browse/Volume_5.../1496476407_03-062017.pdf)

4. Sunilkumar Patel, Karthik Nagarajan and Raju Narwade" Sustainable Smart Blue Roof Network System with application of Geographic Information System (GIS)" International Journal of Engineering Research in Mechanical and Civil Engineering, $\quad$ Vol. 2(3)

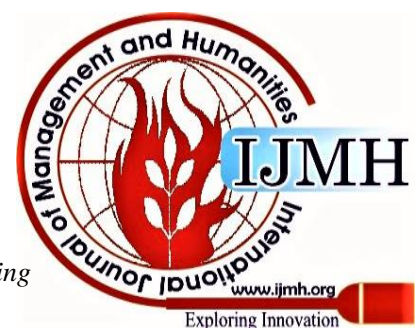




\section{Simulation}

(https://www.researchgate.net/publication/318570727_Sustainable )

5. Pradnya Mawale and Raju Narwade "Traffic Study and Analysis of Project Road (SH-93) Using Pavement Management System" International Journal of Current Engineering and Technology, Vol. No 7(1). (https://www.google.co.in/search?q=Traffic+Study+and+Analysis+of+Proj ect + Road + (SH-93)

6. Suhas G. Awari, Raju Narwade and Manisha Jamgade "Analysis for cause identification for delay in building construction industry" International journal of Modern Trends in Engineering and Research

\section{Awards and Recognitions}

- Recognized Post Graduate Guide, University of Mumbai

- Recognized Post Graduate Teacher, Pune University

- Joint Chief Conductor of examination, University of Mumbai (2012)

- Member of panel for examination for Maharashtra Public Service Commission (2004)

- Engineering Mechanics subject expert in Sasmira Institute of Man- Made Textile, Worli Mumbai (2000)

- Selected for Govt. and ISRO Sponsored Training Programme at Indian Institute of Remote Sensing, Dehradun (2018)

- Syllabus Revision Committee Member for Concrete Technology, Structural Analysis-I and II Courses of UG in Civil EngineeringUniversity of Mumbai.

- Syllabus Revision Committee Member for Total Quality Management in Construction and Construction safety, Energy Conservation Techniques in Building Construction Courses of PG in Civil Engineering-University of Mumbai

- Life Member of ISTE, ISRS, ISH, ASTR and IWWA

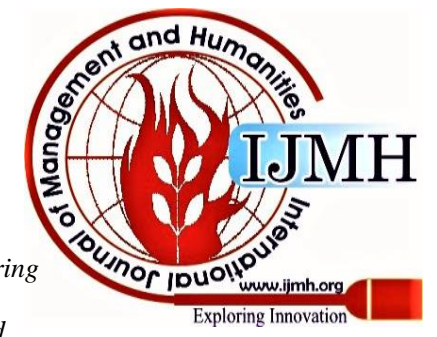

